\title{
Upstream migration of hilsa (Tenualosa ilisha) towards Hakaluki haor: A case study
}

\author{
IFTEKHAR AHMED FAGUN*, SAKIB TAHMID RISHAN ${ }^{1}$ \\ AND NATASA TASNIA SHIPRA ${ }^{1}$ \\ Department of Aquatic Resource Management, Sylhet Agricultural University \\ ${ }^{1}$ Faculty of Fisheries, Sylhet Agricultural University \\ *Email: iftekharfagun@gmail.com
}

\begin{abstract}
The paper was presented at the Fisheries Society of Bangladesh Biennial Conference on Fisheries in the Bangladesh Blue Economy-Challenges and Opportunities
\end{abstract}

\begin{abstract}
Hilsa (Tenualosa ilisha) fishery contributes around 1\% to the national GDP of Bangladesh. Based on a fieldwork the study explored the underlying causes and pathways of Hilsa migration towards Hakaluki Haor and status of Hilsa fishing. To collect empirical data a number of qualitative tools such as interviews, focus group discussion and oral history from different stakeholders were employed. The study identified, though unusual fisher have been netting Hilsa abundantly on early monsoon in Hakaluki haor since 2016. Due to flash flood in the Hakaluki Haor and storm water flows down to the Meghna River through Kushiyara River, hilsa swims against the tide and enters into Hakaluki Haor from the upper Meghna river system. Early flash flood, storm water flows and government's initiative of imposing ban on Hilsa fishing during spawning season in upper Meghna sanctuary were found to be the major causes of migration towards Hakaluki Haor. As impose of ban on fishing of Hilsa increased the total production, abundance of Hilsa in Hakaluki Haor act as an indicator of total inland Hilsa production in Bangladesh. The weight of Hilsa species caught from Hakaluki varied from $200 \mathrm{~g}$ to $900 \mathrm{~g}$ and rarely found $1 \mathrm{~kg}$. The length ranges varied between $10 \mathrm{~cm}$ to 30 $\mathrm{cm}$. The average price was BDT $300-500 / \mathrm{Kg}$. A well-structured marketing channel of Hilsa was identified. The study found some major threats to hilsa population in Hakaluki Haor and made some recommendations to ensure safe migration and conserve migratory Hilsa population in Hakaluki Haor.

Keywords: Upstream migration, Hilsa, Tenualosa ilisha Hakaluki Haor
\end{abstract}

\section{Introduction}

Hilsa shad (Tenualosa ilisha, Hamilton) or River shad is one of the most important tropical anadromous fish species of the Clupeidae family mainly distributed in the Bay of Bengal and widely distributed in the North Indian Ocean is the national fish of Bangladesh. Hilsa shad is locally known as ilish in Bangladesh. In addition, it is one of the major contributors of total fish production in Bangladesh, India and Myanmar. The species is also found in Iran, Iraq, Kuwait, Malaysia, Oman, Pakistan, Saudi Arabia, Sri Lanka, Thailand, United Arab Emirates and Viet Nam (Freyhof 2014). In Bangladesh, about 12\% of country's total fish production comes from hilsa (DoF 2018). Annual hilsa Production from inland waterbodies was 232,066 MT and from marine was 284,500 MT in 2017-18 financial year (DoF 2018). In recent years, hilsa population was found in haor region of northeastern Bangladesh and mainly in Hakaluki haor. Hakaluki haor is one of Bangladesh's largest and one of Asia's larger marsh wetland resources. It lies between $24^{\circ} 35^{\prime} \mathrm{N}$ to $24^{\circ} 44^{\prime} \mathrm{N}$ and $92^{\circ} 00^{\prime} \mathrm{E}$ to $92^{\circ} 08^{\prime} \mathrm{E}$ (Chowdhury and Nishat 2005). The land area of Hakaluki haor is 18,386 hectares (CNRS 2002). It is a complex ecosystem, containing more than 238 interconnecting beels (CWBMP 2005). It is a critical habitat and 
breeding ground for fish and other aquatic species and considered as one of the four major "mother fisheries" in Bangladesh. More than 100 fish species are available in the haor, one third of which are listed as endangered (Chowdhury and Faisal 2005). The study portrayed the underlying causes and pathways of hilsa migration toward hakaluki haor. This study will contribute as the baseline information for further studies on this population.

\section{Materials and Methods}

Study site and period: The study was conducted in the Juri, Borolekha and Kulaura upazilas of Moulvibazar and Fenchuganj upazila of Sylhet Districts from May to September 2019.

Data collection and analysis: Interview, focus group discussion and oral history were employed as qualitative tool to collect empirical data. A total 50 fishers and 15 fish traders from three upazilas were interviewed. The interviews were semi structured which allowed free flowing conversations. Crosschecks interviews were also conducted with key informants such as upazila fisheries officer and community leaders. The collected data were organized and required data were analyzed by the use of Microsoft excel version 2016.

\section{Results and Discussion}

Present status of hilsa population and fishing in hakaluki haor: The present study have found that the fishers have been netting hilsa in hakaluki haor since 2014. Generally, hilsa is caught from river and sea. Though unusual, fishers are catching juvenile hilsa in Hakaluki Haor. During one interview, a fisher stated his experience: "Ten years ago, we've caught two hilsa fish from the haor". In recent years, the catch increased gradually. Fisher netted hilsa in early monsoon in Hakaluki that covers parts of Moulvibazar and Sylhet. A government official from Department of Fisheries in Kulaura upazila, Moulvibazar stated: "In 2019, we've measured the catch from July to mid of September. In addition, the catch was found to be five MT still now. In 2016, 2017, 2018 the catch was found 5 MT, 5.5 MT, and 7 MT respectively." The annual catch of hilsa from hakaluki haor is presented in Fig. 1.

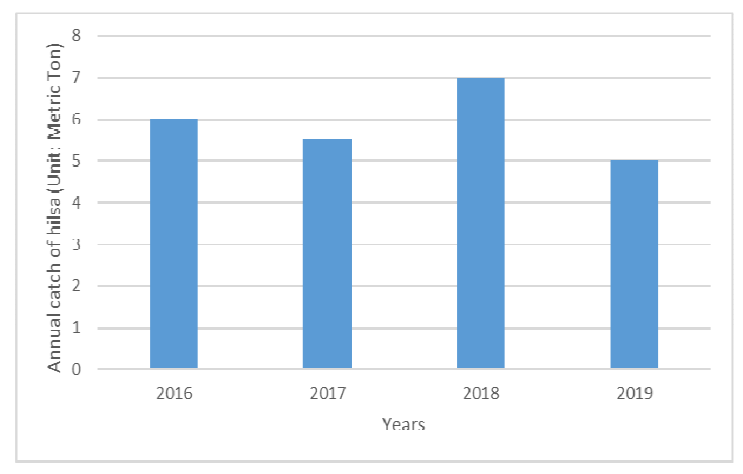

Fig. 1. Annual catch of hilsa from Hakaluki haor from 2016 to 2019.

The weight of Tenualosa ilisha species caught from hakaluki varied from $200 \mathrm{~g}$ to $900 \mathrm{~g}$ and rarely found $1 \mathrm{~kg}$. The average weight was $400 \mathrm{~g}$ which is smaller than the weight of hilsa 
IFTEKHAR AHMED FAGUN et al.

caught from river and sea. The length ranges of juvenile of $T$. ilisha in the study area varied between $10 \mathrm{~cm}$ to $30 \mathrm{~cm}$.

Pathways of hilsa migration toward hakaluki haor: Hilsa migration is synchronous with the increase of the average water flow and increase in average temperature of river water, though a decline in average water temperature with a stable flow does not halt migration. During entire life, Hilsa migrates both from sea to freshwater and freshwater to sea to meet the biological demand. Hilsa lives in the sea for most of its life, but migrates at least 1,200-1,300 km upstream from estuarine region for spawning purpose and it also found about $250 \mathrm{~km}$ distance from coastal region (Halder and Islam 2008). Upper Meghna hilsa sanctuary of Bangladesh is located within two coastal districts of Bangladesh named as Chadpur and Lakshmipur. It lies between $100 \mathrm{~km}$ stretch of Upper Meghna from Shatnol (Chandpur) to Char Alexandar (Lakshmipur). Anadromous hilsa species (T. ilisha) migrates from the Bay of Bengal into the Upper Meghna river freshwater system along with other four hilsa sanctuaries for breeding purpose (Islam et al. 2016). According to Mohammed and Wahab (2013), Meghna river system from Chandpur, Lakshmipur and Bhola were found as the major river nursery ground where juvenile T. ilisha size ranged from 2 to $12 \mathrm{~cm}$ and occurred from November to June. Hilsa starts spawning migration to upstream during the southwest monsoon and consequent flooding of all the rivers (Rahman 2005). Hora (1941) pointed out that among the mature hilsa that swarm into the rivers during the flood season for spawning purposes, there are a number of young individuals also and these travel far up before they become sexually mature. Meghna river freshwater system formed Ganges delta, which fans out to the Bay of Bengal. Meghna is formed inside Bangladesh by the joining of Surma River and Kushiyara River. Kushiyara is a very dynamic river travels over a distance of about $130 \mathrm{~km}$ and flows to the upper Meghna River. The Kushiyara River is connected with hakaluki haor at Juri upazila of Moulvibazar. The river system of the northeastern corner of Bangladesh have played a very significant role in shaping the physical characteristics of Hakaluki haor. The Kushiyara River flows by the northern boundary of the hakaluki haor. The two main rivers, namely the Sonai- Bardal River enters the wetland haor from the east and the Juri River from the southeast. The water level inside Hakaluki haor is governed by the water levels in the Kushiyara River at the outfall of the Juri River. If the water level in the Kushiyara River goes lower than Hakaluki haor, water flows from the study sites to the river. However, if the river's water level higher than that of the study sites, water flows into this wetland from the Kushiyara river as back flow. Kushiyara River is suffering navigability crisis. Water flow from India, 35-40\% flows through the Kushiyara River and the inconsistency of water flow is causing silt deposits and erosion. During last couple of decades is has been found that during the dry season and pre monsoon water levels in the Kushiyara river has increased and it facilitates pre monsoon flood. The present study found due to flash flood in the hakaluki haor and storm water flows down to the Meghna River through Kushiyara River, hilsa swims against the tide and enters into hakaluki haor from upper Meghna river system in early monsoon (Fig. 2).

Causes of hilsa migration toward hakaluki haor: The present study found some causes of hilsa migration toward hakaluki haor from upper Meghna river system. The major causes found from different qualitative approach are navigability crisis of Kushiyara River, early flash flood, storm water flows, government's initiative of establishment of banning periods on hilsa fishing in upper Meghna. 


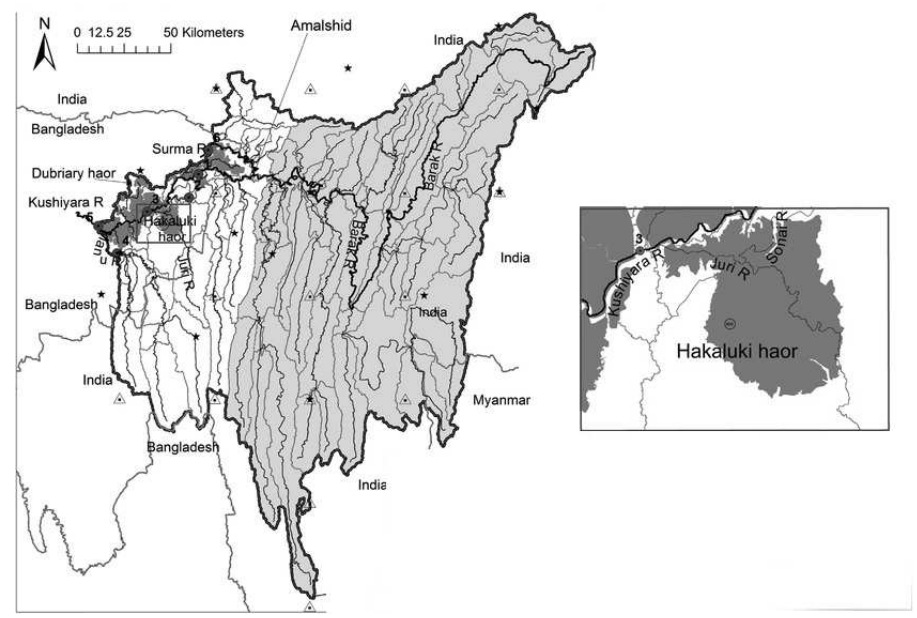

Fig. 2. Entrance site of Tenualosa ilisha in the Hakaluki Haor.

\begin{abstract}
Abundance of hilsa in hakaluki haor is an indicator of total hilsa production in Bangladesh: The volume of catch of hilsa in hakaluki haor however increased in recent years. A government official of Department of Fisheries in Kulaura upazila of Moulvibazar expressed his thoughts: "The government has imposed ban on hilsa fishing on breeding ground to ensure safe spawning. That is why the overfishing of hilsa has been reduced in the river. Hilsa can migrate freely toward upstream. And they can also enter into haor". With a few exceptions, the total annual Hilsa production in Bangladesh increased steadily over the last three decades from 1988 to 2018 . When safe spawning of hilsa can take place and can migrate freely only then they can reach up to hakaluki haor region. As impose of ban on fishing of hilsa and safe spawning increased the total production, abundance of hilsa in hakaluki haor act as an indicator of total inland hilsa production in Bangladesh.
\end{abstract}

Marketing channel of hilsa in hakaluki haor region: The fish traders of Achurighat market of Kulaura upazila, Teghorighat and Kontinala market of Juri upazila, Azimganj, Nababganj, Islamganj market of Baralekha upzaila under Moulvibazar district sell hilsa that have caught from hakaluki haor along with other fish species. One fish trader from Achurighat market stated: "Fishermen of hakaluki haor caught hilsa abundantly in recent years. We sell them in market. People buy interestingly the hilsa of haor" The average price of hilsa was found BDT $300-500 / \mathrm{Kg}$. One buyer expressed his feelings during interview and stated: "Hilsa of hakaluki haor are not tasty like the hilsa of sea and rivers. But we buy because of cheap rate and curiosity". One fisher of hakaluki haor stated: "We can sell the hilsa that we caught from haor to the market. That's why we are very happy." Hilsa fish of hakaluki haor marketed by following a channel, which is presented in a flow diagram (Fig. 3). 


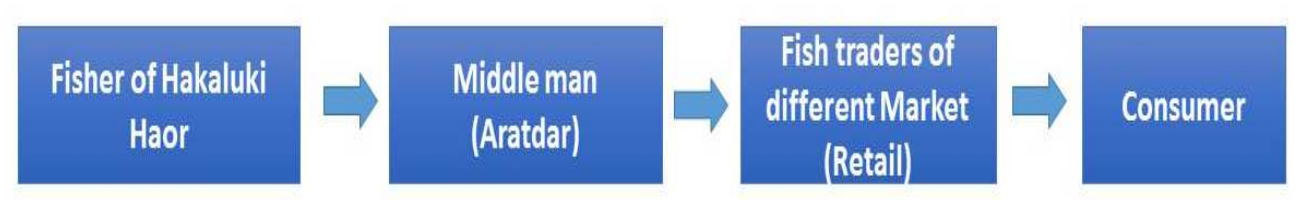

Fig. 3. Marketing channel of Hilsa caught from Hakaluki Haor.

Threats to hilsa population in hakaluki haor: Some major threats were found for hilsa population in hakaluki haor during different interviews and group discussions. One organizer from fisher's community in the study area stated: "Buri keari dam was established in Fenchuganj upazila of Sylhet district. And the dam creates obstacle to the water flow from hakaluki haor to Kushiyara River". The major threats include-

- Construction of dam and embankment

- Siltation in riverbeds

- Habitat modification, fragmentation and destruction

- Overfishing and increased fishing efforts

- Environmental pollution

- Navigability crisis and decreases of water carrying capacity of haor

- Establishment of brick field and other illegal structures on haor

Recommendation: The results revealed that hilsa population from upper Meghna enters into hakaluki haor every year. Moreover, there are some major threats on that population. Based on literature review, observations, interview with relevant stakeholders, the research analysis has identified the following steps or recommendations to ensure safe migration and conserve hilsa population in Hakaluki haor.

- The unplanned Buri keari dam in Fenchuganj upazila under Sylhet district should be removed. A new well-planned dam should be constructed with facilities of upstream fish passage to protect the upazila from flood, ensure the natural water flow between river and haor and ensure the safe migration of hilsa.

- Integrated water resource management should be applied properly for solution of continuous erosion and deposition of large sediment load, which affects in riverbank stabilization, navigation, flood control, fisheries and agriculture.

- Nature-like Bypass Channels should be constructed for upstream migration of hilsa toward hakaluki haor. The nature-like bypass channel is a waterway designed for fish passage around a particular obstruction, which is very similar to a natural tributary of the river. As noted by Parasiewitz et al. (1998), the function of a nature-like bypass channel is, to some degree, restorative in that it replaces a portion of the flowing water habitat, which has been lost due to impoundment.

- Eviction drive should be conducted to free the haor from encroachment.

- Dredging operations should be executed on the upper Kushiyara River. Then the navigability crisis might be averted. 
UPSTREAM MIGRATION OF HILSA TOWARDS HAKALUKI HAOR

- Awareness program should be carried out to stop illegal fishing of hilsa. Ban on catch of juvenile hilsa also should be imposed in haor region.

- Fishing community based co-management committee should be established.

- Pesticide use should be limited in the haor region.

\section{Conclusions}

Hilsa fish is remarked as the as the geographical indicator of Bangladesh. Hilsa production contribute in national economy of Bangladesh. To ensure spawn migration of this species further study is required. Moreover, to increase inland hilsa production necessary steps should be taken.

\section{Literature Cited}

Choudhury, G.A. and A. Nishat, 2005. A hydro-meteorological characteristics of Hakaluki Haor. IUCN Bangladesh Country Office, Dhaka, Bangladesh, 91 p.

Choudhury, J.K. and A.M. Faisal, 2005. Plant Resources of Haors and Floodplains: an Overview. IUCNThe World Conservation Union. Bangladesh Country office, Dhaka.140 p.

CNRS (Centre for Natural Resource Study), 2002. Bio-physical characteristics of Hakaluki Haor. 7-20.

Coastal and Wetland Biodiversity Management Project Document (CWBMP), 2005. Hakaluki Haor Management Plan (Draft). Prepared \& Submitted by: IUCN-Bangladesh. In association with Center for Natural Resource Studies.

DoF, 2018. Yearbook of Fisheries Statistics of Bangladesh, 2017-18. Fisheries resource survey system (FRSS), Department of fisheries, Bangladesh: Ministry of fisheries, 2018. Volume 35: $129 \mathrm{p}$.

Freyhof, J., 2014. Tenualosa ilisha. The IUCN Red List of Threatened Species 2014.

Halder, G.C. and M.R. Islam, 2008. Ilish Mach Sangrakhan abang Unnoun Babashthapona koushal (In Bengali) (Hilsa Fisheries Conservation, Development and Management Technique), Department of Fisheries (DoF), Dhaka, Bangladesh. 1-40.

Hora, S.L., 1941. Life history and wanderings of hilsa in Bengal waters. J. Asiat. Soc. (Sci.), 6(2): 93112.

Islam M.M., N. Islam, A.R. Sunny, S. Jentoft, M.H. Ullah and S.M. Sharifuzzaman, 2016. Fishers' perceptions of the performance of hilsa shad (Tenualosa ilisha) sanctuaries in Bangladesh, Ocean \& Coastal Management, 130: 309-316

Mohammed E.Y. and M.A. Wahab, 2013. Direct economic incentives for sustainable fisheries management: The case of hilsa conservation in Bangladesh. International Institute for Environment and Development, London.

Parasiewicz P., J. Eberstaller, S. Weiss and S. Schmutz, 1998. Conceptual guidelines for natural-like bypass channels. In: M. Jungwirth, S. Schmutz \& S. Weiss (eds.). Fish migration and fish bypasses. Oxford, UK, Fishing News Books, Blackwell Science. 348-362.

Rahman, M.J., M.A. Wahab, S.M.N. Amin, M. Nahiduzzaman and N. Romano, 2018. Catch trend and stock assessment of Hilsa Tenualosa ilisha using digital image measured length-frequency data. Mar Coast Fish., 10: 386-401. doi:10.1002/mcf2.10034

Rahman, M., 2005. The story of the Hilsa shad. [12 November, 2007] http://asiaarecipe.com/banchad.html 